\title{
Cancer mortality among workers in the meat department of supermarkets
}

\author{
Eric S Johnson
}

\begin{abstract}
Objectives-The aim was to study the risk of dying from cancer among workers in the meat department of supermarkets potentially exposed to oncogenic retroviruses and fumes during the wrapping and labelling of meat.
\end{abstract}

Methods-Cancer mortality for the period 1949 to 1989 was compared in a previously studied cohort of $10841 \mathrm{mem}$ bers of a local meatcutters' union in Baltimore, Maryland who worked in the meat department of supermarkets, after an extended follow up of nine years (1981-9). Person-years and deaths were apportioned in five-year intervals by sex, age, and calendar year, and standardised mortality ratio (SMR) and proportional mortality ratio (PMR) analyses were conducted. The United States general population was used as the comparison group. Analyses of SMR and PMR were also conducted for a control group of workers from the same union who worked exclusively in non-meat companies.

Results and discussion-Among women, an SMR of $1.6(95 \%$ confidence interval (95\% CI) $1 \cdot 1-2 \cdot 2)$ and a PMR of $1.5(95 \%$ CI $1 \cdot 0-2 \cdot 0)$ for lung cancer were found. For men, the SMR for cancer of the buccal cavity and pharynx was $1.8(95 \% \mathrm{CI}$ $1 \cdot 0-3 \cdot 0)$, and for colon cancer it was 1.5 (95\% CI $1 \cdot 1-2 \cdot 1)$. The respective PMRs were $1.9(95 \% \mathrm{CI} 1 \cdot 1-3 \cdot 1)$ and $1.5(95 \% \mathrm{CI}$ $1 \cdot 1-2 \cdot 1)$. Whereas the role of non-occupational factors needs to be taken into account before occupational factors can be implicated in the occurrence of the excess of cancer of the buccal cavity and pharynx, and colon cancer in men, there is reason to suspect that occupational factors may be responsible for the lung cancer excess in women. Thus exposures that occur predominantly in women, such as exposure to fumes during wrapping and labelling, should be investigated as to their role in this excess.

(Occup Environ Med 1994;51:541-547)

Excess risk of certain cancers, particularly lung cancer, has consistently been reported among workers in the meat industry. ${ }^{1-12}$ Occupational exposures with carcinogenic potential included (1) the oncogenic viruses of cattle and chickens ${ }^{13-17}$ : (2) fumes emitted when heat is applied through a hot wire or rod to cut the plastic film used to wrap meat, and when heat is applied to a plate or wire elements to activate the adhesive in price labels. These fumes contain hydrogen chloride, plasticisers phthalates and adipates, phthalic anhydride, and small amounts of benzene and other hydrocarbons ${ }^{18-21}$; (3) nitrosamines formed during the curing of meat ${ }^{22}$; (4) the antioxidants butylated hydroxytoluene (BHT) and butylated hydroxyanisole (BHA) used as preservatives $^{2324}$; and (5) polynuclear aromatic hydrocarbons (PAHs) formed during the smoking of meat. ${ }^{25}$

We previously studied mortality for the period 1949-80 in a cohort of 28900 members of a local meatcutters' union in Baltimore, Maryland. ${ }^{1-4}$ The union drew its membership from the meat department of supermarkets, abattoirs, meat packing plants, and chicken slaughtering plants, and from outside the meat industry (non-meat) such as those working in the soft drinks and soup manufacturing, oyster shucking industries etc. The population comprised subjects who were already members of this union as from 1 July 1949 , and subjects who joined subsequently until 1979. Membership in the union was compulsory within 30 days of the start of employment.

Certain cancers including lung cancer were in excess. In men, the lung cancer excess was restricted to those working in abattoirs and meatpacking plants. In women, the lung cancer risk was much higher than that in men, and was more generalised, occurring not only in those working in abattoirs and meatpacking plants, but also in those working in chicken slaughtering plants, and in the meat department of supermarkets. ${ }^{2}$ We therefore conducted a nested case-control study of lung cancer within the cohort. ${ }^{5}$ Fairly strong evidence was provided from this study linking excess lung cancer in men with putative exposure to oncogenic viruses. The study was too small, however, to adequately investigate the other occupational risk factors such as curing and smoking of meat, fumes during wrapping, etc. Also, the risk in women was not investigated specifically because of small numbers.

A study of workers in the meat department of supermarkets would potentially offer a unique opportunity for investigating specifically the role of exposure to fumes during wrapping and labelling in the occurrence of excess cancer in the meat industry. The reason, is that processing activities such as smoking and curing of meat are typical of meat packing plants, and do not normally occur in 
supermarkets. Hence exposure to nitrosamines, PAH, BHT, and BHA would be absent in supermarkets, except possibly for negligible amounts of residues in the meat itself. On the other hand, useful information on the role of the remaining two candidate exposures (oncogenic viruses and fumes during wrapping and labelling), may be reliably obtained, if cancer risk is studied separately in men and women in the meat department of supermarkets, for the following reasons: In the meat department of supermarkets, there is a difference in the tasks men and women do. The department ordinarily consists of three sections: (a) a raw meat section where meat received from abattoirs or meat packing plants is cut up into smaller customised parts, weighted, wrapped, and labelled; $(b)$ a delicatessen section where partially or fully cooked meat is cut, weighted, wrapped, and labelled. Some cooking such as barbecuing of chickens in closed electrically heated vessels may be carried out in situ; (c) a seafood section where weighing, wrapping and labelling are also done. In the delicatessen and seafood sections men and women do exactly the same jobs. In the raw meat section, however, men and women work side by side, and handle the same meat, but their jobs differ. Women are almost exclusively engaged in wrapping and labelling of meat and spend virtually all their time in this activity, whereas men are primarily engaged in meat cutting, and will only occasionally wrap meat when there is a functional shortage of staff.

Because of these sex differences associated with meat cutting and meat wrapping activities, excess cancer seen in women, but appreciably less or absent in men, would likely be associated with meat wrapping and labelling activities, whereas similar excess risk in men and women or a slightly higher risk in men, would likely be associated with exposure to the other candidate-namely, oncogenic viruses. (The intensity of exposure to oncogenic viruses is expected to be either the same for men and women, or slightly higher in men; men and women handle exactly the same meat, except that those men who are meat cutters are more prone to cuts. Hence for them, there is an increased likelihood for viruses to penetrate the skin.

Before 1975, exposure to fumes during meat wrapping and labelling was a problem in supermarket workers in the United States. It caused acute noxious effects on the respiratory mucosa and generally referred to as meatwrappers' asthma. ${ }^{26}$ Different plastics have been used to wrap meat, starting with cellophane in the early $1950 \mathrm{~s}$, rubber hydrochloride, polyethylene, polystyrene, polyvinylidene chloride, and polyvinyl chloride (PVC), which has been in use since 1963. ${ }^{27} 28$ Benzene is a thermal decomposition product of virtually all of the different plastics used to wrap meat. ${ }^{29}$ Smoke produced by burning PVC is believed to be mainly due to the presence of aromatic pyrolytic decomposition products, especially benzene. ${ }^{31}$ The major components resulting from the pyrolysis of
PVC or polyethylene resin include hydrogen chloride, benzene, toluene, and PAHs such as naphthalene. ${ }^{1831}$ Constituents of fumes from PVC film pyrolysis, include, hydrogen, chloride, phthalates, phthalic anhydride, adipates, benzene, PAHs such as naphthalenes, and other hydrocarbons. ${ }^{18213132}$ Thus these fumes contain low concentrations of at least three compounds that are known carcinogens: benzene, which causes leukaemia and possibly lymphoma in humans, ${ }^{33}{ }^{34}$ and is a multicarcinogen in animals, causing a variety of tumours including those of the haemopoietic/lymphatic systems and lungs ${ }^{35}$; phthalates, which cause hepatocellular carcinomas and possibly myelomonocytic leukaemia in rodents ${ }^{36}$; and PAHs, such as benz(a)pyrene, which induced lung tumour and leukaemia in animals, ${ }^{37}$ and are constituents of tobacco smoke, hence contributing to lung cancer in humans. Exposure to coal tar pitches and coal tar that contain PAHs results in the development of lung cancer, leukaemia, and other cancers in humans. ${ }^{33} 38$

Benzene concentrations in area air sampling of up to eight hours were $0.02-0.04$ parts per million (ppm; 0.06 to $0.14 \mathrm{mg} / \mathrm{m}^{3}$ ), and personal air concentrations of as much as 0.03 to $0.16 \mathrm{ppm}\left(0.1-0.5 \mathrm{mg} / \mathrm{m}^{3}\right)$ have been recorded in connection with use of a labelling machine. ${ }^{39}$ Similar values when extrapolated over an eight hour shift were obtained in a simulated experiment cutting PVC plastic films. ${ }^{32}$ In a biomarker study of meat wrappers and meat cutters in supermarkets we detected concentrations of muconic acid (a metabolite of benzene) in the urine of a few workers, compatible with exposure to 1 to $2 \mathrm{ppm}$ benzene (unpublished data). These concentrations are important, as they approach levels of exposure at which benzene causes cancer in humans..$^{40}$ Although subject to some statistical uncertainty, current risk estimates indicate that exposure to as low as 1 to $5 \mathrm{ppm}$ benzene for 40 years results in a threefold risk of leukaemia in humans, ${ }^{40}$ and to $1 \mathrm{ppm}$ for 15 years results in a twofold risk of tumours of the haematopoietic/lymphatic system. ${ }^{41}$

Phthalates have been reported in these fumes at concentrations of up to $3 \cdot 7 \mathrm{mg} / \mathrm{m}^{3} .{ }^{39}$ Although specific PAHs such as naphthalenes have been found in these fumes, actual values are not available.

We report here on cancer mortality after an additional nine years of follow up (1981-9) in the subset of the Baltimore cohort, consisting of 10841 men and women who ever worked in the meat department of supermarkets, and the comparison group of 6265 men and women in the same union who worked exclusively in non-meat companies. The total number of deaths in supermarket workers for the first follow up (1949-80) was 865. In this extended follow up a further 766 deaths were recorded. This paper reports on standardised mortality ratio (SMR) and proportional mortality ratio (PMR) analyses of the total of 1631 deaths that had occurred among supermarket workers and 1202 deaths in non-meat workers, during the combined follow up period of 1949-89. 


\section{Methods}

The original cohort has been described in detail before. ${ }^{1-3}$ As we had conducted a comprehensive follow up in the first study for the period 1949-80, ${ }^{12}$ for this extended follow up only the National Death Index and Social Security Administration Mortality File were used. Also, we manually searched for matching death certificates at the State Department of Vital Records, from all identifying information we had on our records, for the rest of the cohort who were not identified as dead by these two methods (including those with missing date of birth or social security number). After this, persons not identified as dead from these death file searches were assumed to be alive. Based on the methods of follow up we had employed, death ascertainment was regarded as virtually complete.

Although the records for this union were complete to the extent that the record of anyone who had ever been a member could be retrieved, the race and sex of members were not routinely recorded and date of birth was missing for a few members. Thus although these items were available for all dead subjects from their death certificates, they were missing for persons not known to have died. We carried out both SMR and PMR analyses, as this deficiency was a factor in the SMR but not in the PMR analysis. We carried out the following procedures for the SMR analysis: For persons not known to have died, (1) we randomly assigned a race to each subject based on the racial distribution of dead subjects with death certificates. ${ }^{1}$ This distribution was found to be virtually the same among a sample of current members of the union; (2) sex was determined based on first name; (3) date of birth was artifically assigned to 672 subjects in supermarkets and 668 subjects in non-meat companies without this information, as described previously. ${ }^{1}$

Cause specific SMRs and PMRs were calculated with the $\mathrm{O} / \mathrm{E}$ system computer program developed jointly by the National Cancer Institute and IMS Inc as a modification of the Monson program. The reference population was the United States general population. ${ }^{42}$

In the PMR analysis, the expected number of deaths for a given cause was based on the proportion of all deaths due to that cause in the United States population multiplied by the total number of all deaths in the study group, by age, calendar time, race, and sex. The PMR is given as the ratio of the observed number of deaths divided by the expected number. For significance testing, the MantelHaenszel $\chi^{2}$ test with one degree of freedom was used; the variance was determined by the Poisson approximation (the mean of the expected deaths). Ninety five per cent confidence intervals (95\% CIs) were based on Mietinnen's test based formula. ${ }^{42}$ In the SMR analysis, all subjects without death certificates (which includes all subjects with missing demographic information) were assumed to be alive. Expected deaths for a given cause were calculated by partitioning person-years at risk within the study group into age, calendar time, sex, and race categories and multiplying by the respective rates for that cause in the United States reference population. Enumeration of person-years began as from 1 July 1949 for subjects who were already in the union before this date, or from the date of first payment of dues for subjects who joined subsequently, until 31 December 1989, or until death, whichever was earlier.

In the enumeration of person-years in the SMR analysis, date of first payment of union dues was used as a surrogate of date of first exposure or employment, because, as mentioned, union membership was compulsory within 30 days of date of employment. This was appropriate only for subjects who first started work in a company after it joined the union. This measure is not valid for subjects who had worked in companies for a variable number of years before their companies joined the union. Such workers would have accumulated in some cases significant durations of exposure before coming under observation. Such a group has been referred to as a "prevalent" or "cross sectional" cohort. It has been shown that bias may result in risk estimation when a prevalent cohort constitutes part of the study population. ${ }^{434}$ To examine this in the SMR analyses, we further selected a subset of 7740 supermarket workers who were first employed at least one year after their companies had joined the union-thus all of these workers would have come under observation from their date of first employment or exposure, and constitute an "incident" cohort. ${ }^{43}$

We prefer to present the full results using the SMR analyses, even though they are based on incomplete demographic data, for the following reasons: (1) The SMR does not have the inherent disadvantage of a PMR, which is that the investigator does not know whether cause specific PMR results have underestimated or overestimated the true risks, because of the dependency of these PMRs on the overall mortality in the study population compared with that in the comparison group. ${ }^{45} 46$ (2) As the racial distribution of the union has not changed with time, it was reasoned that there should be negligible error, in randomly assigning race as we did, as the proportions of person-years assigned to each race for subjects not known to have died would closely resemble the true ones. (3) The SMR analysis allowed more readily for more detailed analyses such as examination by year of termination of employment, year of first employment, incident cohort etc. (4) The SMR analyses permitted the determination of the direction of bias in the PMR results, which was based on complete data.

\section{Results}

Table 1 gives the race and sex distributions of all deaths in the supermarket workers for each period of follow up.

Table 2 gives the cause specific SMR results. For men in the meat department of 
Table 1 Distribution of deaths by race and sex for each follow up period

\begin{tabular}{|c|c|c|c|c|}
\hline \multirow[b]{2}{*}{$\begin{array}{l}\text { Race/sex } \\
\text { group }\end{array}$} & \multicolumn{2}{|c|}{ Previous follow up } & \multicolumn{2}{|l|}{ Present study } \\
\hline & $\begin{array}{l}\text { Supermarkets/ } \\
\text { grocery stores }\end{array}$ & $\begin{array}{l}\text { Non-meat } \\
\text { companies }\end{array}$ & $\begin{array}{l}\text { Supermarkets/ } \\
\text { grocery stores }\end{array}$ & $\begin{array}{l}\text { Non-meat } \\
\text { companies }\end{array}$ \\
\hline $\begin{array}{l}\text { White men } \\
(6343)^{\star}[2081]+\end{array}$ & 676 & 236 & 1112 & $395 \ddagger$ \\
\hline Non-white men & 57 & 216 & 92 & $340 \ddagger$ \\
\hline $\begin{array}{l}\text { Men } \\
(6906) \star[3903]\end{array}$ & 733 & 452 & 1204 & $735 \ddagger$ \\
\hline $\begin{array}{l}\text { White women } \\
(3749)^{\star}[1167] \dagger\end{array}$ & 177 & 136 & 414 & $231 \ddagger$ \\
\hline $\begin{array}{l}\text { Non-white women } \\
(186)^{\star}[1195] \dagger\end{array}$ & 10 & 145 & 13 & $236 \ddagger$ \\
\hline $\begin{array}{l}\text { Women } \\
(3935)^{\star}[2362] \dagger\end{array}$ & 187 & 281 & 427 & $467 \ddagger$ \\
\hline $\begin{array}{l}\text { All race and sex } \\
\text { groups } \\
(10841)[6265]\end{array}$ & 920 & 733 & 1631 & $1202 \ddagger$ \\
\hline
\end{tabular}

*Estimated number of subjects in supermarkets (since race was estimated)

tEstimated number of subjects in non-meat companies (since race was estimated)

$\ddagger$ Includes subjects who worked in both meat and non-meat companies.

supermarkets, statistically significant excesses of cancer of the buccal cavity and pharynx and colon cancer were found. For women, only lung cancer was significantly in excess. (In supermarket women, the results reflect

Table 2 Standardised mortality ratios (SMRs) for subjects who ever worked in the meat department of supermarkets/grocery stores, and for those who worked exclusively in nonmeat companies

\begin{tabular}{|c|c|c|c|c|}
\hline \multirow{2}{*}{$\begin{array}{l}\text { Cause of death } \\
\text { (ICD) }\end{array}$} & \multicolumn{2}{|l|}{ Supermarket } & \multicolumn{2}{|l|}{ Non-meat } \\
\hline & Men & Women & Men & Women \\
\hline All causes & $\begin{array}{l}0.9 \\
{[0.9-0.99]^{\star}} \\
(1204)\end{array}$ & $\begin{array}{l}1 \cdot 0 \\
{[0 \cdot 9-1 \cdot 1]} \\
(427)\end{array}$ & $\begin{array}{l}0.9 \\
{[0.9-0.99]^{\star}} \\
(710)\end{array}$ & $\begin{array}{l}0.8 \\
{[0.7-0.9]^{\star}} \\
(455)\end{array}$ \\
\hline $\begin{array}{l}\text { All cancers } \\
(140-209)\end{array}$ & $\begin{array}{l}1 \cdot 0 \\
{[0 \cdot 9-1 \cdot 2]} \\
(290)\end{array}$ & $\begin{array}{l}1 \cdot 0 \\
{[0 \cdot 9-1 \cdot 2]} \\
(153)\end{array}$ & $\begin{array}{l}1 \cdot 0 \\
{[0 \cdot 9-1 \cdot 2]} \\
(160)\end{array}$ & $\begin{array}{l}0 \cdot 9 \\
{[0 \cdot 7-1 \cdot 0]} \\
(126)\end{array}$ \\
\hline $\begin{array}{l}\text { Buccal/pharynx } \\
(140-149)\end{array}$ & $\begin{array}{l}1 \cdot 8 \\
{[1 \cdot 0-3 \cdot 0]^{\star}} \\
(15)\end{array}$ & $\begin{array}{l}1 \cdot 5 \\
{[0 \cdot 3-4 \cdot 4]} \\
(3)\end{array}$ & $\begin{array}{l}1 \cdot 7 \\
{[0 \cdot 8-3 \cdot 2]} \\
(10)\end{array}$ & $\begin{array}{l}0 \cdot 5 \\
{[0 \cdot 0-2 \cdot 6]} \\
(1)\end{array}$ \\
\hline $\begin{array}{l}\text { Stomach } \\
\text { (151) }\end{array}$ & $\begin{array}{l}1 \cdot 0 \\
{[0 \cdot 5-1 \cdot 8]} \\
(12)\end{array}$ & $\begin{array}{l}0 \cdot 9 \\
{[0 \cdot 2-2 \cdot 7]} \\
(3)\end{array}$ & $\begin{array}{l}0.9 \\
{[0 \cdot 4-1 \cdot 9]} \\
(7)\end{array}$ & $\begin{array}{l}2 \cdot 0 \\
{[0 \cdot 9-3 \cdot 6]} \\
(10)\end{array}$ \\
\hline $\begin{array}{l}\text { Colon } \\
\text { (153) }\end{array}$ & $\begin{array}{l}1 \cdot 5 \\
{[1 \cdot 1-2 \cdot 1]^{\star}} \\
(36)\end{array}$ & $\begin{array}{l}0 \cdot 6 \\
{[0 \cdot 3-1 \cdot 2]} \\
(8)\end{array}$ & $\begin{array}{l}0.9 \\
{[0 \cdot 4-1 \cdot 6]} \\
(10)\end{array}$ & $\begin{array}{l}1 \cdot 3 \\
{[0 \cdot 8-2 \cdot 0]} \\
(18)\end{array}$ \\
\hline $\begin{array}{l}\text { Pancreas } \\
(157)\end{array}$ & $\begin{array}{l}1 \cdot 0 \\
{[0 \cdot 6-1 \cdot 7]} \\
(14)\end{array}$ & $\begin{array}{l}0 \cdot 9 \\
{[0 \cdot 3-2 \cdot 0]} \\
(5)\end{array}$ & $\begin{array}{l}1 \cdot 1 \\
{[0 \cdot 5-2 \cdot 1]} \\
(8)\end{array}$ & $\begin{array}{l}0 \cdot 4 \\
{[0 \cdot 1-1 \cdot 2]} \\
(3)\end{array}$ \\
\hline $\begin{array}{l}\text { Lung } \\
(162)\end{array}$ & $\begin{array}{l}1 \cdot 1 \\
{[0 \cdot 9-1 \cdot 3]} \\
(102)\end{array}$ & $\begin{array}{l}1 \cdot 6 \\
{[1 \cdot 1-2 \cdot 2]^{\star}} \\
(40)\end{array}$ & $\begin{array}{l}1 \cdot 3 \\
{[1 \cdot 0-1 \cdot 6]^{\star}} \\
(69)\end{array}$ & $\begin{array}{l}1 \cdot 2 \\
{[0 \cdot 8-1 \cdot 8]} \\
(25)\end{array}$ \\
\hline $\begin{array}{l}\text { Breast } \\
(174)\end{array}$ & $\bar{E}=0.4$ & $\begin{array}{l}0 \cdot 7 \\
{[0 \cdot 5-1 \cdot 1]} \\
(26)\end{array}$ & $\bar{E}=0.2$ & $\begin{array}{l}0 \cdot 7 \\
{[0 \cdot 4-1 \cdot 1]} \\
(21)\end{array}$ \\
\hline $\begin{array}{l}\text { All uterus } \\
(180-182)\end{array}$ & NA & $\begin{array}{l}1 \cdot 3 \\
{[0 \cdot 7-2 \cdot 3]} \\
(14)\end{array}$ & NA & $\begin{array}{l}0.9 \\
{[0 \cdot 5-1 \cdot 5]} \\
(14)\end{array}$ \\
\hline $\begin{array}{l}\text { Other genital } \\
(183-184)\end{array}$ & NA & $\begin{array}{l}1 \cdot 1 \\
{[0 \cdot 6-2 \cdot 0]} \\
(12)\end{array}$ & NA & $\begin{array}{l}1 \cdot 0 \\
{[0 \cdot 5-1 \cdot 9]} \\
9\end{array}$ \\
\hline $\begin{array}{l}\text { All genital } \\
(180-184)\end{array}$ & NA & $\begin{array}{l}1 \cdot 2 \\
{[0 \cdot 8-1 \cdot 8]} \\
(26)\end{array}$ & NA & $\begin{array}{l}0.9 \\
{[0 \cdot 6-1 \cdot 4]} \\
(23)\end{array}$ \\
\hline $\begin{array}{l}\text { Prostate } \\
\text { (185) }\end{array}$ & $\begin{array}{l}1 \cdot 2 \\
{[0 \cdot 7-1 \cdot 8]} \\
(19)\end{array}$ & NA & $\begin{array}{l}0 \cdot 7 \\
{[0 \cdot 3-1 \cdot 4]} \\
(8)\end{array}$ & NA \\
\hline $\begin{array}{l}\text { Lymphoma reticulosarcoma } \\
(200)\end{array}$ & $\begin{array}{l}0 \cdot 7 \\
{[0 \cdot 1-2 \cdot 0]} \\
(3)\end{array}$ & $\begin{array}{l}1 \cdot 1 \\
{[0 \cdot 1-3 \cdot 9]} \\
(2)\end{array}$ & $\bar{E}=1.9$ & $\bar{E}=1.5$ \\
\hline $\begin{array}{l}\text { Hodgkin's disease } \\
(201)\end{array}$ & $\begin{array}{l}0 \cdot 6 \\
{[0 \cdot 1-2 \cdot 2]} \\
(2)\end{array}$ & $\begin{array}{l}0.9 \\
{[0 \cdot 0-5 \cdot 0]} \\
(1)\end{array}$ & $\begin{array}{l}0 \cdot 7 \\
{[0 \cdot 0-3 \cdot 7]} \\
(1)\end{array}$ & $\bar{E}=0.8$ \\
\hline $\begin{array}{l}\text { Myeloma } \\
(203)\end{array}$ & $\begin{array}{l}1 \cdot 3 \\
{[0 \cdot 4-3 \cdot 0]} \\
(5)\end{array}$ & $\begin{array}{l}1 \cdot 6 \\
{[0 \cdot 3-4 \cdot 8]} \\
(3)\end{array}$ & $\overline{\mathrm{E}}=2.5$ & $\begin{array}{l}1 \cdot 1 \\
{[0 \cdot 2-3 \cdot 3]} \\
(3)\end{array}$ \\
\hline $\begin{array}{l}\text { Leukaemia } \\
(204-207)\end{array}$ & $\begin{array}{l}0 \cdot 5 \\
{[0 \cdot 2-1 \cdot 2]} \\
(6)\end{array}$ & $\begin{array}{l}1 \cdot 3 \\
{[0 \cdot 5-2 \cdot 8]} \\
(6)\end{array}$ & $\begin{array}{l}0 \cdot 8 \\
{[0 \cdot 2-1 \cdot 9]} \\
(4)\end{array}$ & $\bar{E}=4 \cdot 1$ \\
\hline $\begin{array}{l}\text { Other lymphatic } \\
(202,203,208)\end{array}$ & $\begin{array}{l}0 \cdot 7 \\
{[0 \cdot 2-1 \cdot 4]} \\
(6)\end{array}$ & $\begin{array}{l}1 \cdot 6 \\
{[0 \cdot 6-3 \cdot 3]} \\
(7)\end{array}$ & $\begin{array}{l}0 \cdot 2 \\
{[0 \cdot 0-1 \cdot 1]} \\
(1)\end{array}$ & $\begin{array}{l}0 \cdot 7 \\
{[0 \cdot 1-1 \cdot 9]} \\
(3)\end{array}$ \\
\hline $\begin{array}{l}\text { All haematopoeitic/lymphatic } \\
(200-209)\end{array}$ & $\begin{array}{l}0.6 \\
{[0.3-0.95]^{\star}} \\
(17)\end{array}$ & $\begin{array}{l}1 \cdot 4 \\
{[0 \cdot 8-2 \cdot 2]} \\
(17)\end{array}$ & $\begin{array}{l}0.4 \\
{[0 \cdot 2-0.9]^{\star}} \\
(6)\end{array}$ & $\begin{array}{l}0.4 \\
{[0.1-0.9]^{\star}} \\
(4)\end{array}$ \\
\hline
\end{tabular}

${ }^{\star} \mathrm{p}<0.05\left(\chi^{*}\right.$ test $)$

tExcludes all subjects who ever worked in the meat industry.

$\ddagger$ Figures in parentheses are numbers of observed deaths; figures in brackets [ ] are $95 \% \mathrm{CIs}$; $\mathrm{E}=$ number of expected deaths; $\mathrm{NA}=$ not applicable. mostly the experience of white women, as there were only two cancer deaths in nonwhite women.)

When the cause specific SMRs given in table 2 for male and female supermarket workers were compared with the corresponding cause specific PMR results (not presented), they were all found to be virtually identical. When these were compared with cause specific results from the incident cohort analysis, again virtually identicial results were achieved, even when the groups were broken down by race and sex. There were two exceptions: the SMR for cancer of the uterus in white women in supermarkets of $1.5(95 \% \mathrm{CI}$ $0 \cdot 8-2 \cdot 5)$ was similar to the corresponding PMR of 1.5 (95\% CI 0.8-2.6), but different from the corresponding SMR of $2 \cdot 3(95 \% \mathrm{CI}$ $1 \cdot 2-4 \cdot 0)$ in the incident cohort. This may be of no relevance as the SMR in the control group of non-meat white women was also 1.5 (95\% CI 0.6-3.1). In non-white supermarket men, although the SMR of $2.5(95 \% \mathrm{CI}$ $0 \cdot 7-6 \cdot 4)$ and that of $2 \cdot 2(95 \%$ CI $0 \cdot 0-12 \cdot 3)$ in the incident cohort for stomach cancer were similar, the corresponding PMR was $3 \cdot 7$ (95\% CI $1 \cdot 0-9 \cdot 4)$ (table 3$)$. It is likely that this PMR is artifically inflated, resulting from the lower all causes mortality in non-white supermarket workers $(S M R=0.6)$ compared with the United States general population.

Table 3 compares statistically significant results of the two SMR and the PMR analyses in this study, with those obtained in the previous follow up, by race and sex. To rule out any bias in the SMR results due to artificial assignment of race, further analyses (worst case scernario) were carried out in which all supermarket workers were classified as whites by sex, and then as non-whites by sex, using the appropriate United States reference death rates each time. In Table 3 it is seen that for cancer of the buccal cavity and pharynx in men, for which there are pronounced racial differences in the United States rates, the SMR results obtained for supermarket workers were similarly divergent. On the other hand, for colon cancer in men and lung cancer in women, for which the corresponding rates in the United States population were similar in both races, the results were essentially unchanged. These findings suggest that the possibility of any bias resulting from our artifically assigning race in the main SMR analyses can be ruled out for the findings of excess colon cancer in male and excess lung cancer in female supermarket workers.

Table 4 gives the lung cancer SMR results by calendar year of termination of employment (exposure), year of first employment, and calendar year of death, in the incident cohort. Examination of risk by year of termination and by year of first employment shows that for men, no significant excess risk was found for those who worked in supermarkets after 1954. By contrast, despite the much smaller number of deaths in women, there was a statistically significant excess of lung cancer in women who stopped work as early as 1955-9 and as late as 1970-4. Similarly, 
Table 3 Summary of statistically significant results for supermarket workers compared with the previous follow up, and the incident cohort, and classifying all subjects as white or non-white by sex

\begin{tabular}{|c|c|c|c|c|c|c|c|c|}
\hline \multirow{4}{*}{$\begin{array}{l}\text { Supermarket } \\
\text { workers } \\
\text { Race/sex } \\
\text { group }\end{array}$} & \multirow[b]{4}{*}{$\begin{array}{l}\text { Cancer } \\
\text { site }\end{array}$} & & & \multicolumn{5}{|l|}{$S M R$} \\
\hline & & & & \multirow[b]{3}{*}{$\begin{array}{l}\text { Previous } \\
\text { follow up }\end{array}$} & \multicolumn{4}{|l|}{ Present study } \\
\hline & & \multicolumn{2}{|l|}{$P M R$} & & \multirow[b]{2}{*}{$\begin{array}{l}\text { Full } \\
\text { cohort }\end{array}$} & \multirow[b]{2}{*}{$\begin{array}{l}\text { incident } \\
\text { cohort }\end{array}$} & \multirow{2}{*}{$\begin{array}{l}\text { All } \\
\text { subjects } \\
\text { classified } \\
\text { as white } \\
\text { by sex }\end{array}$} & \multirow{2}{*}{$\begin{array}{l}\text { All } \\
\text { subjects } \\
\text { classified } \\
\text { as } \\
\text { non-white }\end{array}$} \\
\hline & & $\begin{array}{l}\text { Previous } \\
\text { follow up }\end{array}$ & $\begin{array}{l}\text { Present } \\
\text { study }\end{array}$ & & & & & \\
\hline $\begin{array}{l}\text { White } \\
\text { men }\end{array}$ & $\begin{array}{l}\text { Buccal } \\
\text { cavity and } \\
\text { pharynx } \\
\text { Colon }\end{array}$ & NA & $\begin{array}{l}1 \cdot 9 \\
{[1 \cdot 1-3 \cdot 3]^{\star}} \\
\mathrm{n}=14 \\
1 \cdot 6 \\
{[1 \cdot 1-2 \cdot 2]^{\star}} \\
\mathrm{n}=35\end{array}$ & $\begin{array}{l}1 \cdot 8 \\
{[0 \cdot 7-3 \cdot 6]} \\
n=7 \\
1 \cdot 8 \\
{[1 \cdot 0-2 \cdot 8]^{\star}} \\
n=18\end{array}$ & $\begin{array}{l}1 \cdot 9 \\
{[1 \cdot 1-3 \cdot 2]^{\star}} \\
\mathrm{n}=14 \\
1 \cdot 6 \\
{[1 \cdot 1-2 \cdot 2]^{\star}} \\
\mathrm{n}=35\end{array}$ & $\begin{array}{l}2 \cdot 4 \\
{[0 \cdot 9-5 \cdot 2]} \\
\mathrm{n}=6 \\
1 \cdot 4 \\
{[0 \cdot 7-2 \cdot 5]} \\
\mathrm{n}=10\end{array}$ & $\begin{array}{l}1 \cdot 9 \\
{[1 \cdot 1-3 \cdot 2]^{\star}} \\
\mathrm{n}=15 \\
1 \cdot 5 \\
{[1 \cdot 1-2 \cdot 1]^{\star}} \\
\mathrm{n}=36\end{array}$ & $\begin{array}{l}0 \cdot 9 \\
{[0 \cdot 5-1 \cdot 5]} \\
\mathrm{n}=15 \\
1 \cdot 5 \\
{[1 \cdot 1-2 \cdot 1]} \\
\mathrm{n}=36\end{array}$ \\
\hline $\begin{array}{l}\text { White } \\
\text { women }\end{array}$ & Lung & $\begin{array}{l}2 \cdot 2^{*} \\
\text { NA }\end{array}$ & $\begin{array}{l}1 \cdot 5 \\
{[1 \cdot 1-2 \cdot 1]^{\star}} \\
n=40\end{array}$ & $\begin{array}{l}1 \cdot 9 \\
{[1 \cdot 0-3 \cdot 1]^{\star}} \\
n=14\end{array}$ & $\begin{array}{l}1 \cdot 7 \\
{[1 \cdot 2-2 \cdot 3]^{\star}} \\
n=40\end{array}$ & $\begin{array}{l}1 \cdot 7 \\
{[1 \cdot 0-2 \cdot 6]^{\star}} \\
\mathrm{n}=20\end{array}$ & $\begin{array}{l}1 \cdot 6 \\
{[1 \cdot 2-2 \cdot 2]^{\star}} \\
\mathrm{n}=40\end{array}$ & $\begin{array}{l}1 \cdot 7 \\
{[1 \cdot 2-2 \cdot 4]^{\star}} \\
n=40\end{array}$ \\
\hline
\end{tabular}

${ }^{\star}$ Statistically significant at the $95 \%$ confidence level. Figures in brackets [ ] are $95 \%$ CIs; NA = not available.

there seems to be an increased risk for women first employed for each interval between 1950 and 1974. Examination of risk by calendar year of death shows that in both sexes, risk of lung cancer began to fall after 1974 .

We refer briefly to results for tumours of the haematopoietic and lymphatic systems because we were especially interested in these tumours, as they are the sites commonly involved in virally induced tumours in cattle and chickens, and in benzene induced cancer. Although there was a definite deficit of tumours of the haematopoietic and lymphatic systems (ICD 8th revision 200-209) in supermarket men which was also seen in the control group, women in supermarkets seem to show an excess $(S M R=1 \cdot 4)$, even when compared with women in the control group $(\mathrm{SMR}=0.4 ; 95 \% \mathrm{CI} 0 \cdot 1-0.9))$. This is more apparent, considering that even though the total number of all deaths among men of 1204 was almost three times the total number of deaths in women of 427 , the total number of deaths from tumours of the haematopoietic and lymphatic systems in both sexes was 17 each. There were four lymphomas in men compared with five in women, and five tumours of the erythroid and myeloid series in men compared with eight in women.
Although these data are limited, they seem to show an excess of these tumours in women compared with men.

\section{Discussion}

The consistency between the PMR and SMR results (including those of the incident cohort) indicates that the results overall probably approximate closely to the true risks, and any bias is likely to be minimal.

Previous studies have reported an excess risk of cancer of the buccal cavity and pharynx among butchers, meat cutters, and workers in meat packing plants. ${ }^{147}$ The excess in supermarket men in this study, however, may be of no relevance, as a similar risk was also seen in the control group of male non-meat workers, and thus may simply reflect a high background rate of this disease in the study area. The general population of Baltimore city from which most of the study population is derived, is known to have a significantly higher rate of cancer of the buccal cavity and pharynx than the United States general population. ${ }^{48}$

Similarly, the excess risk of colon cancer in butchers and meat cutters, and in food processors has been reported before. ${ }^{12} 49$ The cause of the excess of colon cancer in male

Table 4 Lung cancer SMRs for incident cohort, by year of termination of employment, by year of first employment, and by calendar year of death

\begin{tabular}{|c|c|c|c|c|c|c|}
\hline \multirow[b]{2}{*}{ Period } & \multicolumn{3}{|l|}{ White men } & \multicolumn{3}{|c|}{ White women } \\
\hline & $\begin{array}{l}\text { SMR for } \\
\text { subjects who } \\
\text { terminated } \\
\text { employment }\end{array}$ & $\begin{array}{l}\text { SMR for } \\
\text { subjects } \\
\text { who were first } \\
\text { employed }\end{array}$ & $\begin{array}{l}\text { SMR for } \\
\text { subjects } \\
\text { who died }\end{array}$ & $\begin{array}{l}\text { SMR for } \\
\text { subjects who } \\
\text { terminated } \\
\text { employment }\end{array}$ & $\begin{array}{l}\text { SMR for } \\
\text { subjects } \\
\text { who were first } \\
\text { employed }\end{array}$ & $\begin{array}{l}\text { SMR for } \\
\text { subjects } \\
\text { who died }\end{array}$ \\
\hline $1950-4$ & $\begin{array}{l}3 \cdot 2 \\
{[1 \cdot 0-7 \cdot 4]^{\star}}\end{array}$ & $\begin{array}{l}2 \cdot 1 \\
{[0 \cdot 9-4 \cdot 2]}\end{array}$ & $\overline{\mathrm{E}}=0.0$ & $\begin{array}{l}1 \cdot 1 \\
{[0 \cdot 0-6 \cdot 3]}\end{array}$ & $\begin{array}{l}2 \cdot 4 \\
{[0 \cdot 8-5 \cdot 6]}\end{array}$ & $\overline{\mathrm{E}}=0.0$ \\
\hline $1955-9$ & $\begin{array}{l}0 \cdot 7 \\
{[0 \cdot 2-1 \cdot 4]}\end{array}$ & $\begin{array}{l}0 \cdot 7 \\
{[0 \cdot 3-1 \cdot 2]}\end{array}$ & $\bar{E}=0.2$ & $\begin{array}{l}2 \cdot 8 \\
{[1 \cdot 2-5 \cdot 5]^{\star}}\end{array}$ & $\begin{array}{l}1 \cdot 6 \\
{[0 \cdot 7-3 \cdot 2]}\end{array}$ & $\begin{array}{l}24 \cdot 5 \\
{[0-140]}\end{array}$ \\
\hline $1960-4$ & $\begin{array}{l}0.6 \\
{[0 \cdot 2-1 \cdot 4]}\end{array}$ & $\begin{array}{l}1 \cdot 3 \\
{[0 \cdot 6-2 \cdot 4]}\end{array}$ & $\bar{E}=0.7$ & $\begin{array}{l}0.5 \\
{[0 \cdot 0-2 \cdot 8]}\end{array}$ & $\begin{array}{l}1 \cdot 1 \\
{[0 \cdot 2-3 \cdot 3]}\end{array}$ & $\bar{E}=0.2$ \\
\hline $1965-9$ & $\begin{array}{l}{[\cdot 6} \\
{[0 \cdot 7-3 \cdot 1]}\end{array}$ & $\begin{array}{l}1 \cdot 0 \\
{[0 \cdot 4-2 \cdot 0]}\end{array}$ & $\begin{array}{l}1 \cdot 8 \\
{[0 \cdot 4-5 \cdot 2]}\end{array}$ & $\begin{array}{l}2 \cdot 1 \\
{[0 \cdot 4-6 \cdot 0]}\end{array}$ & & $\begin{array}{l}2 \cdot 5 \\
{[0-14]}\end{array}$ \\
\hline $1970-4$ & $\begin{array}{l}1 \cdot 2 \\
{[0 \cdot 4-2 \cdot 7]}\end{array}$ & $\bar{E}=2 \cdot 4$ & $\begin{array}{l}1 \cdot 6 \\
{[0 \cdot 6-3 \cdot 5]}\end{array}$ & $\begin{array}{l}3 \cdot 0 \\
{[1 \cdot 2-6 \cdot 2]^{\star}}\end{array}$ & $\begin{array}{l}1 \cdot 6 \\
{[0 \cdot 2-5 \cdot 5]}\end{array}$ & $\begin{array}{l}6 \cdot 7 \\
{[2 \cdot 5-13 \cdot 1]^{\star}}\end{array}$ \\
\hline $1975-9$ & $\begin{array}{l}0 \cdot 7 \\
{[0 \cdot 3-1 \cdot 5]}\end{array}$ & $\overline{\mathrm{E}}=0.6$ & $\begin{array}{l}1 \cdot 1 \\
{[0 \cdot 4-2 \cdot 3]}\end{array}$ & $\begin{array}{l}1 \cdot 0 \\
{[0 \cdot 3-2 \cdot 5]}\end{array}$ & $\overline{\mathrm{E}}=0.4$ & $\begin{array}{l}0 \cdot 9 \\
{[0 \cdot 1-3 \cdot 3]}\end{array}$ \\
\hline $1980-4$ & - & - & $\begin{array}{l}0.9 \\
{[0.4-1 \cdot 8]}\end{array}$ & - & & $\begin{array}{l}0 \cdot 8 \\
{[0 \cdot 2-2 \cdot 3]}\end{array}$ \\
\hline $1985-9$ & - & - & $\begin{array}{l}0 \cdot 7 \\
{[0 \cdot 3-1 \cdot 3]}\end{array}$ & - & - & $\begin{array}{l}1 \cdot 7 \\
{[0 \cdot 8-3 \cdot 1]}\end{array}$ \\
\hline
\end{tabular}

* Statistically significant at the $95 \%$ confidence level.

†Approaching statistical significance. Figures in brackets [ ] are $95 \%$ CIs; E = expected number of deaths. 
supermarket workers in this study is not known. Viral exposure is a possible candidate for investigation as no excess was found in women. It has been shown experimentally that the presence of wounds (which are more likely occur in male meat cutters than in female wrappers) facilitates the development of cancer induced by oncogenic retroviruses of chickens. ${ }^{50}$ On the other hand, substantial data identifying dietary factors, particularly animal fat and meat consumption, as risk factors for colon cancer exist in the literature. In one of these studies, it was noted that no variable could reduce the correlation with meat consumption to less than $0 \cdot 70 .^{51}$ In view of the fact that one study has reported increased consumption of meat among butchers compared with the general population, ${ }^{49}$ the role of non-occupational factors (particularly diet) needs to be taken into account in future attempts to investigate the disease in this population.

Excess risk for lung cancer has consistently been reported among men in the meat industry. ${ }^{1-12}$ Evidence indicates that exposure to oncogenic viruses may be associated with this excess, ${ }^{511}$ although exposure to PAHs and nitrosamines in connection with smoking and curing of meat could also be relevant. ${ }^{49} 52 \mathrm{We}$ have been the only group to report on lung cancer risk in women, in our original report on the entire Baltimore cohort. We found a high risk of the disease in women who worked in meat packing plants, chicken slaughtering plants, and the meat department of supermarkets. ${ }^{2}$ In this report, we also noted excess risk in women in supermarkets, but not in the men who work side by side with them. We therefore suspect that exposure to fumes during wrapping and labelling may be associated with increased risk of this disease in women, for the following reasons: (1) This is the only major task that women perform in the meat department of supermarkets; (2) in the meat department of supermarkets in the United States, meat wrapping and labelling are predominantly female activities-men usually do not wrap or label; when they do, it has been estimated that they spend no more than $15 \%$ of their time on this activity ( $\mathrm{DH}$ Wegman, unpublished data); (3) as well as supermarkets, this is the only exposure common to women in abattoirs, meatpacking plants, and chicken slaughtering plants, the other areas in which this excess risk has been found; (4) the "hot wire" machine used for wrapping has been in use since the early 1950 s when plastic films were first used to wrap meat. (Not all supermarkets in the study had this machine.) A significant reduction in exposure to wrapping and labelling fumes occurred in supermarkets in the United States after 1975, with the substitution of the "cold rod" in place of the "hot wire" in the wrapping machine. Our SMR results by year of termination, year of first exposure, and year of death showing that excess lung cancer risk has been present in supermarket women from the 1950 s till the end of 1974 seem consistent with this change. It is noted that this fall in risk is also mani- fested by the fall in SMR for these women in our previous study ${ }^{2}$ from 1.9 to 1.7 in this follow up; (5) wrapping and labelling fumes contain benzene, PAHs, and phthalates that are associated with the occurrence of lung cancer and leukaemia in humans or animals. Thus our finding of excess lung cancer and possibly leukaemia and lymphoma in these women, is also consistent.

For these reasons, it is appropriate to suspect that exposure to fumes during wrapping and labelling may be related to the excess lung cancer seen in female but not in male supermarket workers. These results should be regarded as preliminary, however, as they need to be confirmed in other populations. Employment history was not updated for this follow up, and we did not control for tobacco smoking. Because of these caveats, caution should be exercised in the interpretation of the findings. Studies that will take into account non-occupational confounding factors like tobacco smoking are needed to further investigate this apparent association between exposure to fumes during wrapping and labelling, and occurrence of lung cancer in women.

Although use of the "cold rod" has definitely resulted in substantially reducing exposure to fumes, the hot wire machine is still being used in some supermarkets and in other areas of the meat industry such as chicken processing plants and in other industries (personal observation). Also, incorrect use of the cold rod machine by operating it above the recommended temperature, a practice known to occur among some supermarket workers, may still be associated with noticeable exposure to fumes; field measurements have shown that about $10 \%$ of the time a "cool rod" was as hot as a "hot wire" (DH Wegman, unpublished data). It has been shown that operating the cool rod cutter at temperatures of $210^{\circ} \mathrm{C}$ or more results in emission that exceed those obtained with a poor practice hot wire technique. ${ }^{53}$ Thus the potential for exposure to these fumes, although significantly reduced, has not been completely eliminated.

I thank Glen Heartwell, and Charles Knott of Survey Research Associates, and Sukon Kanchanaraksa of the Johns Hopkins Associates, and Sukon Kanchanaraksa of the Johns Hopkins
University, for their valuable assistance in the conduct of this study.

1 Johnson ES, Fischman HR, Matanoski GM, Diamond E Cancer mortality among white males in the meat industry. $\mathcal{F}$ Occup Med 1986;28:23-32.

2 Johnson ES, Fischman HR, Matanoski GM, Diamond E. Occurrence of cancer in women in the meat industry. $\mathrm{Br}$ Occurrence of cancer in wom
f Ind Med 1986;43:597-604.

3 Johnson ES. Mortality among nonwhite men in the meat industry. F Occup Med 1989;31:270-2.

4 Johnson ES, Fischman HR. Cancer mortality among butchers and slaughterhouse workers. Lancet 1982;i: 913-4.

5 Johnson ES. Nested case-control study of lung cancer in the meat industry. $\mathcal{F}$ Natl Cancer Inst 1991;83:1337-9. 6 Fox AJ, Lynge E, Malker H. Lung cancer in butchers. Lancet 1982;i:165-6.

7 Griffith W. Lung cancer in butchers. Lancet 1982;i:399.

8 Lynge E, Andersen O, Kristensen TS. Lung cancer in Danish butchers. Lancet 1983;i:527-8.

9 Doerken $H$, Rehpenning W. Lung cancer in butchers. Lancet 1982;1:561.

10 Reif JS, Pearce NE, Fraser J. Cancer risks among New Zealand meat workers. Scand $\mathcal{f}$ Work Environ Health 1989;15:24-9. 
11 Caggon D, Pannett B, Pippard EC, et al. Lung cancer in the meat industry. $\mathrm{Br} \mathcal{F}$ Ind Med 1989;46:188-91.

12 Siemiatycki J, ed. Risk factors for cancer in the workplace. Boca Raton, Baton Rouge, CRC Press, 1991:225-6.

13 Avian Leukosis. GF De Boer ed. Boston: Martinus Nijhoff, 1987.

14 Witter RI Reticuloendotheliosis virus. In: Hofstad MS, Barnes HJ, Reid WM, Yoder HW Jr, eds. Diseases of poultry. Ames, Iowa: Iowa State University Press, 1984:406-17.

15 Payne LN, ed. Marek's Disease. Scientific basis and method of control. Boston: Martinus Nijhoff Publishing, 1985

16 Burny A, Mammerickx M, eds. Enzootic bovine leukosis and bovine leukemia virus. Boston: Martinus Nijhoff Publishing. 1987.

17 Campo MS. Papillomas and cancer in cattle. Cancer Surv 1987;6:39-54.

18 O'Mara MM. High temperature pyrolysis of poly(vinyl chloride): gaschromatographic-mass spectrometric analysis of the pyrolysis products from PVC resin and plastisols. fourmal of Polymer Science 1970;8:1887-99.

19 Takahashi T, Serizawa M. Pyrolysis of polyvinyl chloride. Plastics Industry News 1972;12:17-21.

20 Polakoff PL, Lapp L, Reger R. Polyvinyl choride pyrolysis products. Arch Environ Health 1975;30:269-71.

21 Vandervort R, Brooks SM. Polyvinyl chloride film thermal decomposition products as an occupational illness. I. Environmental exposures and toxicology. $\mathcal{F}$ Occup Med 1977;19:188-91.

22 Sen NP, Miles WF, Donaldson B, et al. Formation of nitrosamines in meat curing mixture. Nature 1973;245: 104-5.

23 Williams GM, Maeura Y, Weisburger JH. Simultaneous inhibition of liver carcinogenicity and enhancement of bladder carcinogenicity of $\mathrm{N}$-2-fluorenyl-acetamide by bladder carcinogenicity of $\mathrm{N}$-2-fluorenyl-acetamide by

24 Ito N, Fukushima S, Hagiwara A, Shibata M, Ogiso T. Carcinogenicity of butylated hyroxyanisole in F344 rats. F Natl Cancer Inst 1983;70:343-52.

25 Nordholm L, Espensen I, Jensen HS, Holst E. Polycyclic aromatic hydrocarbons in smokehouses. Scand $\mathscr{f}$ Work Environ Health 1986;12:614-8.

26 Sokol WN, Aelony Y, Beall GN. Meat-wrapper's asthma. A new syndrome? $\mathcal{F} A M A$ 1973;226:639-41.

27 Vandervort R, Brooks SM. Health hazard evaluation determination. December 1975. Cincinnati: US Department of Health, Education, and Welfare, National Institute for Occupational Safety and Health, Center for Disease Control, 1975. (Report No 74-24,92,95-246.)

28 Encyclopedia of Polymer Science and Technology. Plastics, resins, rubber, fibers. New York: Interscience Plastics, resins, rubber,

29 Madorsky SL. Thermal degradation of organic polymers. Robert E. Krieger Publishing Company, Huntington, New York: 1975:27-167.

30 Michal J, Mitera J, Tardon S. Toxicity of thermal degradation products of polyethylene and polypropylene. Fire and Materials 1976;1:160-8.

31 Quinn EJ, Ahlstrom DH, Liebman SA. Effect of structure of chlorinated vinyl polymers on smoke evolution. Presented at the American Chemical Society Meeting, 1973. Polymer Preprints 1973;14:1022-7.

32 Cook W. Industrial hygiene evaluation of thermal degradation products from PVC film in meat-wrapping operations. Am Ind Hyg Assoc $\mathcal{F}$ 1980;41:508-12.

33 International Agency for Research on Cancer. Monographs on the evaluation of carcinogenic risks of humans. Overall evaluations of carcinogenicity: an updating of LARC monographs Volumes 1 to 42. Supplement 7. Lyon, France: IARC, 1987.

34 Adamson R, Seiber SM. Chemically-induced leukaemia in humans. Environ Health Perspect 1981;39:93-103.

35 Maltoni C, Ciliberti A, Cotti G, Conti B, Belpoggi F.
Benzene, an experimental multipotential carcinogen: Results of the long-term bioassays performed at the Bologna Institute of Oncology. Environ Health Perspect 1989;82:109-24.

36 Kluwe WM, McConnell EE, Huff JE, Haseman JK, Douglas JF, Hartwell WV. Carcinogenicity testing of phthalate esters and related compounds by the National phthalate esters and related compounds by the National Environ Health Perspect 1982;45:129-33.

37 International Agency for Research on Cancer. Monographs on the evaluation of carcinogenic risk of the chemical to man. Certain polycyclic aromatic hydrocarbons and heterocyclic compounds Volume 3. Lyon, France: IARC 1973.

38 International Agency for Research on Cancer. Monographs on the evaluation of carcinogenic risk of chemicals to humans. Polynuclear aromatic compounds, Part 4, bitumens, coal-tars, and derived products, shale-oils and soots. Volume 35. Lyon, France: IARC 1985.

39 Frederick L, Wilcox T, Moseley C. Health hazard evaluation determination. Cincinnati: US Department of Health and Human Services, National Institute for Occupational Safety and Health, Center for Disease Control, Public Safety and Health, Center for Disease Control, Publi

40 Rinsky RA, Smith AB, Hornung R, Fillson TG, Young RJ, Okun AH, Landrigan PJ. Benzene and leukemia: An epidemiologic risk assessment. $N$ Engl f Med 1987;316: $1044-50$.

41 Wong $O$. An industry-wide mortality study of chemical workers occupationally exposed to benzene. II. Dose response analyses. $\mathrm{Br} \mathcal{F}$ Ind $\mathrm{Med}$ 1987;44:382-95.

$42 \mathrm{O} / \mathrm{E}$ System. Observed versus expected events. User guideVersion 3.7, Fanuary 1990. Epidemiology and biostatistics program, National Cancer Institute and IMS Inc.

43 Johnson ES, Matanoski GM. SMR estimations in "prevalent" cohorts and "incident" cohorts. Med Lav 1987;78: 263-71.

44 Weiss W. Heterogeneity in historical cohort studies: a source of bias in assessing lung cancer risk. 7 Occup Med 1983;25:290-4.

45 Wong $O$, Decoufle $P$. Methodological issues involving the standardized mortality ratio and proportionate mortality ratio in occupational studies. F Occup Med 1982;24: 299-304.

46 Johnson ES. PMR and relative risk, (letter). $\mathrm{Br} f$ Ind Med 1986;43:214-5.

47 Milham Jr S. Occupational mortality in Washington State 1950-1971. Vol 1. Cincinnati: US Department of Health Education and Welfare, Center for Disease Control, National Institute for Occupational Safety and Health. 1976. (Contract No CDC-99-74-26.)

48 Gittelsohn A. Mortality Surveillance Project (1979-1981). Comparison of mortality in the 700 geographic areas in the US, with population greater than 10,000 for the period 1968-1978. Report to the US National Center for Health Statistics. (Unpublished.)

49 Guberan E, Usel M, Raymond L, Fioretta G. Mortality and incidence of cancer among a cohort of self employed butchers from Geneva and their wives. Br $₹$ Ind Med 1993;50:1008-16.

50 Sieweke MH, Thompson NL, Sporn MB, et al. Mediation of wound-related Rous sarcoma virus tumorigenesis by TGF-beta. Science 1990;248:1656-60.

51 Amstrong B, Doll R. Environmental factors and cancer incidence and mortality in different countries, with special incidence and mortality in different countries, with special reference

52 Johnson ES, Dalmas D, Noss J, Matanoski GM. Cancer mortality among abattoir and meatpacking plant workers: an update. Am $\mathcal{F}$ Ind Med 1994 (in press).

53 Smith TJ, Cafarella JJ, Chelton C, Crowley S. Evaluation of emissions from simulated commercial meatwrapping operations using PVC wrap. Am Ind Hyg Assoc $\mathscr{f}$ $1983 ; 44: 176-83$. 